\title{
An efficient preparation of 2-alkyl-oxazoles from 2-iodooxazoles
}

\author{
Xing Zhang ${ }^{\mathrm{a}, \mathrm{b}}$, Jun Liu ${ }^{\mathrm{a}}$, Yi Liu ${ }^{\mathrm{b}}$, Yuguo Du ${ }^{\mathrm{a}, \mathrm{b}, *}$ \\ ${ }^{a}$ State Key Laboratory of Environmental Chemistry and Eco-toxicology, Research Center for Eco-Environmental Sciences, Chinese Academy of Sciences, Beijing 100085, China \\ ${ }^{\mathrm{b}}$ School of Chemistry and Chemical Engineering, University of Chinese Academy of Sciences, Beijing 100049, China
}

\section{A R T I C L E I N F O}

\section{Article history:}

Received 25 March 2013

Revised 15 May 2013

Accepted 20 May 2013

Available online 24 May 2013

\section{Keywords:}

Iodooxazole

2-Alkyl oxazoles

Suzuki reaction

Regioselective alkylation

\begin{abstract}
A B S T R A C T
An efficient synthesis toward 2-alkyl substituted oxazoles has been achieved through Suzuki cross-coupling reaction. Treatment of various alkyl iodides with 9-MeO-BBN, followed by in situ palladium-catalyzed carbon-carbon formation with 2-iodooxazoles obtained the 2-alkyl substituted oxazoles in good to excellent yields. Regioselective C2-alkylation on 2,4-di-iodooxazole under the same reaction conditions was firstly disclosed.
\end{abstract}

(ㄷ) 2013 Elsevier Ltd. All rights reserved.
Oxazoles are widely distributed in natural products, and many of them possess significant biological activities including antifungal, cytotoxic, and anthelmintic properties. ${ }^{1}$ Oxazoles have also been utilized as important building blocks in organic syntheses and drug developments. ${ }^{2,3}$ The potent biological activity and the prevalence of oxazoles in natural products and drug candidates have stimulated intensive interests in the synthesis of these heterocycles. $^{2 \mathrm{~b}, 2 \mathrm{~d}-\mathrm{g}}$

As an important structural motif, 2-alkyl substituted oxazole ring has been found in many oxazole-containing natural products, including the phenoxan, ${ }^{1 \mathrm{~g}}$ noricumazoles, ${ }^{4}$ hennoxazoles, ${ }^{1 \mathrm{f}}$ and leiodolides A \& B. ${ }^{1 \mathrm{~d}}$ Conventional synthesis of 2 -alkyl oxazoles was conducted in multistep reaction, $2 \mathrm{f,5}$ and to the best of our knowledge, direct alkylation at the $\mathrm{C} 2$ position is challenging and has very limited success to date. ${ }^{6}$ Due to the structural significance in drug development, it has a strong demanding to explore new synthetic methodologies to access this highly functionalized heterocycles in a straightforward and efficient way. Herein, we wish to report our result for the synthesis of 2-alkyl-oxazole via Suzuki-Miyaura cross-coupling reaction between 2-iodooxazoles and alkylboronates.

In our efforts toward the total synthesis of leiodolides (Fig. 1), showing potential cytotoxicity against HCT-116 human colon carcinoma cells, ${ }^{1 \mathrm{~d}}$ we have recently reported the stereoselective synthesis of the C22-C31 fragment of leiodolide A employing a diastereoselective Seebach alkylation and a Brown's P2-Ni catalyzed cis-alkyne semihydrogenation in the presence of a vinyl iodide. $^{7}$ To build fragments $\mathrm{C} 1-\mathrm{C} 17$ of leiodolide A, we eagerly

\footnotetext{
* Corresponding author. Tel./fax: +86 1062849126.

E-mail address: duyuguo@rcees.ac.cn (Y. Du).
}

required a method for the facile assembly of this densely functionalized 2-alkyl-substitution oxazole derivative, exemption from multistep construction of the oxazole ring.

The exploration started from a direct alkylation on oxazole C-2 position through $\mathrm{C}-2$ lithiation and a subsequent quenching with an electrophile, using ethyl oxazole-4-carboxylate (3) and iodomethane (4) as the testing system. Treatment of $\mathbf{3}$ with lithium base (LiHMDS or $t$-BuLi) in anhydrous THF, with or without 1,3-dimethyl-3,4,5,6-tetrahydro-2(1H)-pyrimidinone (DMPU), resulted in the recovery of major starting materials. In order to exclude the electron-withdrawing effect of carboxylate at C4-position, TBS group protected substrate 4-(tert-butyl-dimethylsilyloxy)methyloxazole (5) was applied, unfortunately, no desired product was observed. Attempted C-2 alkylation on oxazole through lithium-halogen exchange for ethyl 2-iodooxazole-4-carboxylate $(6)^{8}$ in the presence of lithium reagent and $\mathbf{4}$ also failed to generate the desired 2-methyl oxazole-4-carboxylate. It seems that trapping 2-lithiooxazole with $\mathbf{4}$ was more difficult than we expected due to the mobile equilibrium ${ }^{9}$ between oxazole anion $7 \mathbf{a}$ and $\alpha$-isocyano enolate $\mathbf{7 b}$ (Scheme 1 ).

We then turned our attention to the palladium-catalyzed B-alkyl Suzuki-Miyaura cross-coupling, as shown in Table $1 .^{10}$ Initial studies were focused on the screening of a suitable coupling condition between 1-iodobutane (8a) and oxazolyl substrate $\mathbf{6}$. Several common palladium catalyst precursors, such as $\mathrm{Pd}\left(\mathrm{PPh}_{3}\right)_{4}$, $\mathrm{Pd}\left(\mathrm{PPh}_{3}\right)_{2} \mathrm{Cl}_{2}$, and $\mathrm{Pd}(\mathrm{dba})_{2}$ were tested, and did not give encouraging results under the standard Suzuki coupling conditions (entries 1-3). Fortunately, we found that $\mathrm{Pd}(\mathrm{OAc})_{2}$ in the presence of $\mathrm{AsPh}_{3}$ and $\mathrm{K}_{3} \mathrm{PO}_{4}$ provided the desired product $9 \mathrm{a}$ in $37 \%$ yield (entry 6 ). Inspired by this finding, we next investigated other coupling reagents and conditions, and were pleased to find that $\mathrm{Pd}(\mathrm{dppf}) \mathrm{Cl}_{2}$ 


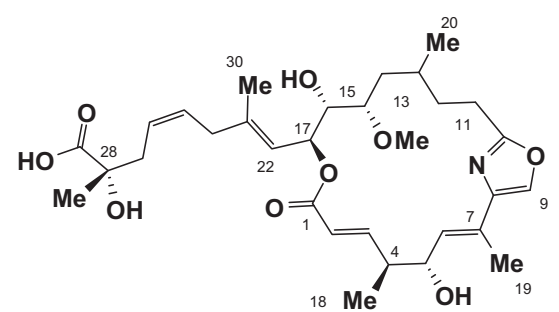

Leiodolide A , (1)

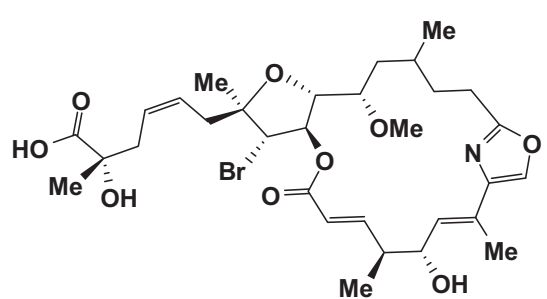

Leiodolide B, (2)

Figure 1. Structures of leiodolides A and B.

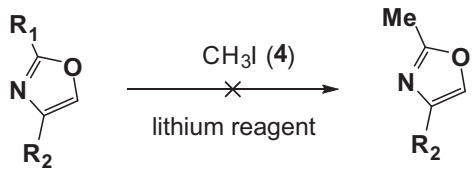

$3 \mathrm{R}_{1}=\mathrm{H}, \mathrm{R}_{2}=$ COOEt

$5 \mathrm{R}_{1}=\mathrm{H}, \mathrm{R}_{2}=\mathrm{CH}_{2} \mathrm{OTBS}$

$6 \mathrm{R}_{1}=\mathrm{I}, \mathrm{R}_{2}=\mathrm{COOEt}$

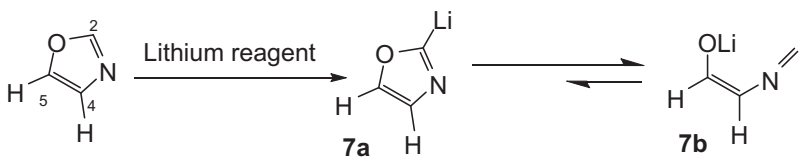

Scheme 1. Attempted C-2 alkylation on oxazole using lithium reagents.

could generate the desired product 9a in 75\% yield (entry 7). Thus an optimized coupling reaction was established as follows: To a solution of alkyl iodide (1.3 equiv) and 9-methoxy-BBN (3.42 equiv) in $\mathrm{Et}_{2} \mathrm{O}\left(1 \mathrm{~mL}\right.$ ) at $-78^{\circ} \mathrm{C}$ was added $t$-BuLi (3.0 equiv) rapidly. After $5 \mathrm{~min}$, THF $(1 \mathrm{~mL})$ was added. The solution was stirred for $30 \mathrm{~min}$ at $-78{ }^{\circ} \mathrm{C}$ and then allowed to warm to room temperature over $1 \mathrm{~h}$. In a separate flask, 2-iodooxazole $(0.094 \mathrm{mmol}$, 1.0 equiv) was taken up in $1 \mathrm{~mL}$ of $\mathrm{DMF}$ to which $\mathrm{Pd}(\mathrm{dppf}) \mathrm{Cl}_{2}$ (10\%), $\mathrm{AsPh}_{3}(15 \%), \mathrm{Cs}_{2} \mathrm{CO}_{3}$ (4.0 equiv), and $\mathrm{H}_{2} \mathrm{O}$ (24.0 equiv) were added sequentially. Then the ethereal solution of alkyl boronate was transferred into the DMF solution, and the resulting mixture was stirred for $12 \mathrm{~h}$ (entry 9).

We also investigated the scope and limitation of this reaction by treatment of various alkyl halides with iodooxazole derivatives
(Table 2). Coupling of $\mathbf{6}$ with alkyl iodides, with or without branched chain structures, afforded the products in good to excellent yields (entries 1-6) under the above optimized reaction conditions. Previously failed coupling reaction between 6 and iodomethane through lithium-halogen exchange was also achieved in moderate yield (61\%, entry 3 ). More importantly, the valuable building block $\mathbf{8 f ^ { 1 1 }}$ in our synthesis of leiodolide A also accomplished the corresponding alkyl oxazole 9 f in 92\% yield (entry 6). However, reaction of the alkyl or benzyl bromide (entries 7-8), as well as the secondary iodide (entry 9), with oxazole 6 was proved to be inefficient under current conditions. ${ }^{12}$ The same procedure performed on other functionalized iodooxazole substrates, such as oxazolyl compound 10, also furnished good results suggesting a wide substrate adaptability of this method (entry10).

Recently, Strotman et al. ${ }^{13}$ reported a direct arylation on disubstituted 2,4-di-iodo-oxazole (11) to prepare bis- and tris-oxazole molecules and demonstrated the possibility of catalyst-controlled regioselective Suzuki couplings at 2- or 4-position of 11. Inspired by their elegant pioneer work, we studied the alkylation of 11 with different alkyl iodides under our conditions. We were pleased to find that the cross-coupling reaction was carried out smoothly affording 2-alkyl-4-iodooxazole as the only coupling product in good yields (entries 11-14). Confirmation of this selectivity was exemplified by lithiation of 4-iodooxazole $\mathbf{9 j}$ with $n$ BuLi, and quenching with $\mathrm{H}_{2} \mathrm{O}$ to obtain the known compound 2butyloxazole. ${ }^{14}$ To the best of our knowledge, there is no literature precedent about the regioselective 2-alkylation on 2,4-di-iodooxazole. This result implies that the current method is applicable to the synthesis of differentially substituted 2,4-di-alkyl-oxazoles,

\section{Table 1}

Optimization for one-pot B-alkyl Suzuki cross-coupling

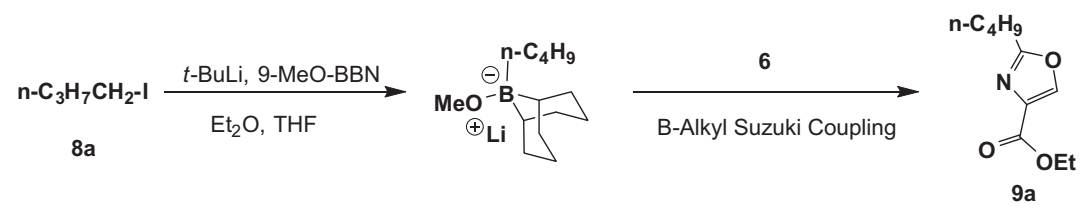

\begin{tabular}{|c|c|c|c|c|}
\hline Entry & Reagent sources and solvent ${ }^{\mathrm{a}}$ & $T\left({ }^{\circ} \mathrm{C}\right)$ & Time (h) & Yield $^{\mathrm{b}}(\%)$ \\
\hline 1 & $\mathrm{Pd}\left(\mathrm{PPh}_{3}\right)_{2} \mathrm{Cl}_{2}, \mathrm{~K}_{3} \mathrm{PO}_{4}, \mathrm{H}_{2} \mathrm{O}, \mathrm{DMF}$ & rt to reflux & 12 & Trace \\
\hline 2 & $\mathrm{Pd}\left(\mathrm{PPh}_{3}\right)_{4}, \mathrm{NaOH}, \mathrm{H}_{2} \mathrm{O}, \mathrm{THF}$ & $\mathrm{rt}$ & 24 & $\mathrm{ND}^{\mathrm{c}}$ \\
\hline 3 & $\mathrm{Pd}(\mathrm{dba})_{2}, \mathrm{AsPh}_{3}, \mathrm{Cs}_{2} \mathrm{CO}_{3}, \mathrm{H}_{2} \mathrm{O}, \mathrm{DMF}$ & $\mathrm{rt}$ & 24 & ND \\
\hline 4 & $\mathrm{Pd}(\mathrm{OAc})_{2}, \mathrm{AsPh}_{3}, \mathrm{Cs}_{2} \mathrm{CO}_{3}, \mathrm{H}_{2} \mathrm{O}, \mathrm{DMF}$ & $\mathrm{rt}$ & 24 & ND \\
\hline 5 & $\mathrm{Pd}(\mathrm{dppf}) \mathrm{Cl}_{2}, \mathrm{~K}_{3} \mathrm{PO}_{4}, \mathrm{H}_{2} \mathrm{O}, \mathrm{DMF}$ & $\mathrm{rt}$ & 12 & 5 \\
\hline 6 & $\mathrm{Pd}(\mathrm{OAc})_{2}, \mathrm{AsPh}_{3}, \mathrm{~K}_{3} \mathrm{PO}_{4}, \mathrm{H}_{2} \mathrm{O}, \mathrm{DMF}$ & $\mathrm{rt}$ & 12 & 37 \\
\hline 7 & $\mathrm{Pd}(\mathrm{dppf}) \mathrm{Cl}_{2}(5 \%), \mathrm{AsPh}_{3}, \mathrm{Cs}_{2} \mathrm{CO}_{3}, \mathrm{H}_{2} \mathrm{O}, \mathrm{DMF}$ & $\mathrm{rt}$ & 12 & 75 \\
\hline 8 & $\mathrm{Pd}(\mathrm{dppf}) \mathrm{Cl}_{2}, \mathrm{AsPh}_{3}, \mathrm{~K}_{3} \mathrm{PO}_{4}, \mathrm{H}_{2} \mathrm{O}, \mathrm{DMF}$ & $\mathrm{rt}$ & 12 & 85 \\
\hline 9 & $\mathrm{Pd}(\mathrm{dppf}) \mathrm{Cl}_{2}, \mathrm{AsPh}_{3}, \mathrm{Cs}_{2} \mathrm{CO}_{3}, \mathrm{H}_{2} \mathrm{O}, \mathrm{DMF}$ & $\mathrm{rt}$ & 12 & 91 \\
\hline
\end{tabular}

a Unless otherwise noted, 2-iodooxazole ( $0.094 \mathrm{mmol}, 1.0$ equiv), $n$ - $\mathrm{C}_{3} \mathrm{H}_{7} \mathrm{CH}_{2}$-I (1.3 equiv), $t$-BuLi (3.0 equiv), 9-methoxy-BBN (3.42 equiv), Et ${ }_{2} \mathrm{O}$ (1 $\mathrm{mL}$ ), DMF (1 mL), the palladium catalyst precursors (10\%), $\mathrm{AsPh}_{3}(15 \%), \mathrm{Cs}_{2} \mathrm{CO}_{3}$ (4.0 equiv), $\mathrm{K}_{3} \mathrm{PO}_{4}$ (3.0 equiv), $\mathrm{NaOH}$ (4.0 equiv), and $\mathrm{H}_{2} \mathrm{O}(24.0$ equiv) were used.

b Isolated yield.

c No desired product. 
Table 2

Pd-catalyzed B-alkyl Suzuki cross-coupling of iodooxazoles with halides ${ }^{\text {a }}$

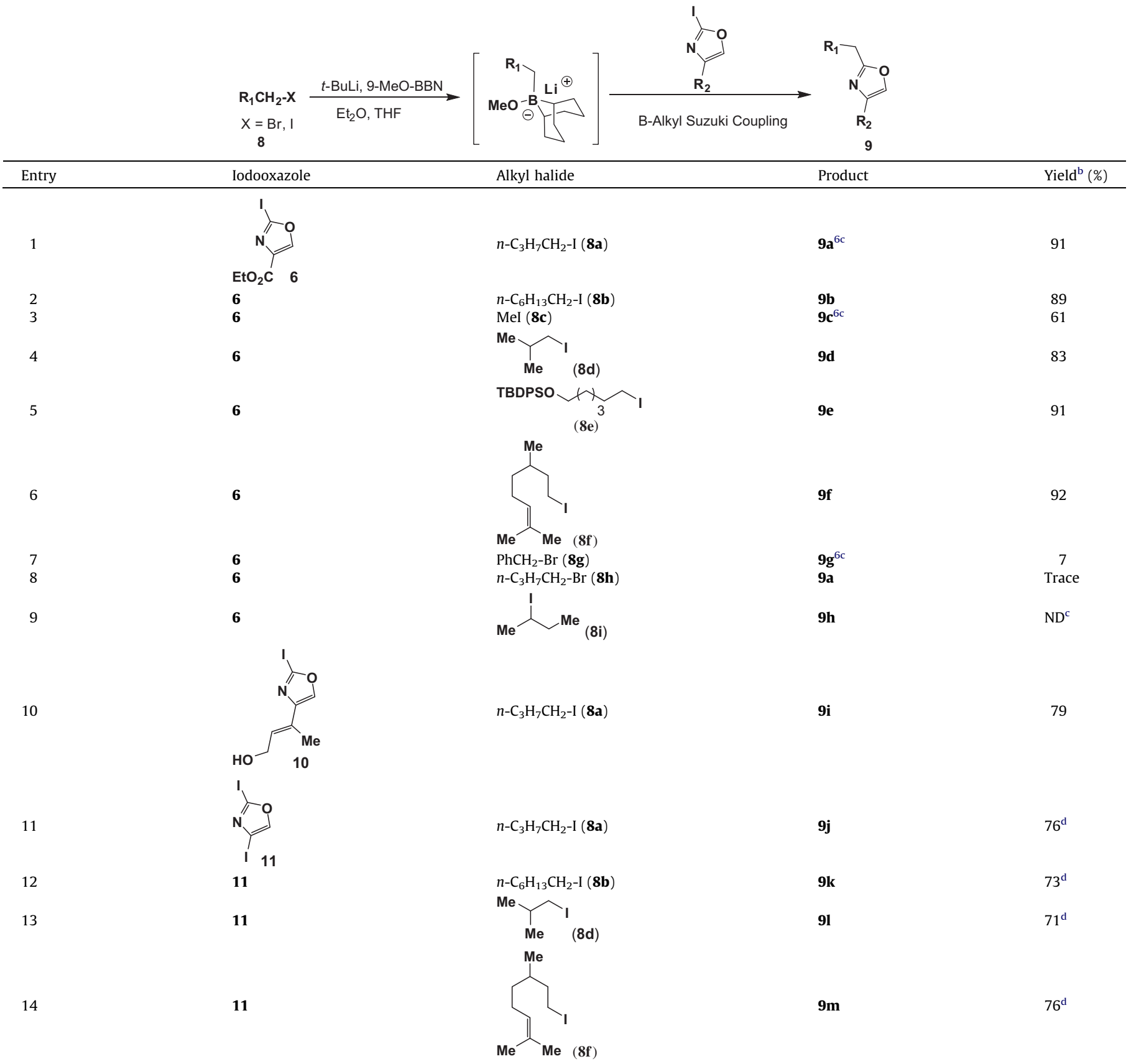

${ }^{a}$ Unless otherwise noted, the $\mathrm{Pd}(\mathrm{dppf}) \mathrm{Cl}_{2}(10 \%), \mathrm{AsPh}_{3}$ (15\%), $\mathrm{Cs}_{2} \mathrm{CO}_{3}$ (4.0 equiv), and $\mathrm{H}_{2} \mathrm{O}$ (24.0 equiv) were used, then the alkyl boronate solution was added and stirred for $12 \mathrm{~h}$ at room temperature.

b Isolated yield.

c No desired product.

d No 2,4-disubstituted or 4-substituted product was observed.

and is a good complement to the existing methods for oxazole syntheses.

In conclusion, we have developed an efficient method toward 2-alkyl substituted oxazoles through alkylborane mediated Suzuki cross-coupling in good to excellent yields. The first example of palladium-catalyzed regioselective alkylation on 2,4-diiodooxazole is also disclosed. This method could provide a new facile synthetic approach toward 2,4-disubstituted oxazolyl natural product synthesis. Expansion of the protocol scope and application of this methodology to the total synthesis of leiodolides are currently underway in our group.

\section{Acknowledgments}

This work was supported by the MOST of China (Projects 2012ZX09502001-001 and 2012CB822101) and NNSF of China (Projects 21072217 and 21202193). 


\section{Supplementary data}

Supplementary data (experimental procedure, ${ }^{1} \mathrm{H}$ and ${ }^{13} \mathrm{C}$ NMR data of new compounds) associated with this article can be found, in the online version, at http://dx.doi.org/10.1016/j.tetlet.2013.05. 088.

\section{References and notes}

1. For examples of oxazole-containing natural products, see: (a) Adamczeski, M.; Quinoa, E.; Crews, P. J. Am. Chem. Soc. 1988, 110, 1598-1602; (b) Kato, Y.; Fusetani, N.; Matsunaga, S.; Hashimoto, K.; Fujita, S.; Furuya, T. J. Am. Chem. Soc. 1986, 108, 2780-2781; (c) Raju, R.; Gromyko, O.; Fedorenko, V.; Luzhetskyy, A.; Müller, R. Tetrahedron Lett. 2012, 53, 3009-3011; (d) Sandler, J. S.; Colin, P. L.; Kelly, M.; Fenical, W. J. Org. Chem. 2006, 71, 7245-7251; (e) Searle, P. A.; Molinski, T. F. J. Am. Chem. Soc. 1995, 117, 8126-8131; (f) Ichiba, T.; Yoshida, W. Y.; Scheuer, P. J.; Higa, T.; Gravalos, D. G. J. Am. Chem. Soc. 1991, 113, $3173-$ 3174; (g) Jansen, R.; Kunze, B.; Wray, V.; Reichenbach, H.; Jurkiewicz, E.; Hunsmann, G.; Höfle, G. Liebigs Ann. 1991, 707-708; (h) Jin, Z. Nat. Prod. Rep. 2009, 26, 382-455; (i) Jin, Z. Nat. Prod. Rep. 2005, 22, 196-229; (j) Jin, Z.; Huang, R. Nat. Prod. Rep. 2002, 19, 454-476.

2. (a) Palmer, D. C.; Taylor, E. C. Oxazoles: Synthesis, Reactions, and Spectroscopy, Part A In The Chemistry of Heterocyclic Compounds; Wiley: New Jersey, NJ, 2004; Vol. 60, For reviews of oxazole synthesis and reactions, see: (b) Yeh, V. S. C. Tetrahedron 2004, 60, 11995-12042; (c) Lipshutz, B. H. Chem. Rev. 1986, 86, 795-819; For examples of oxazole-containing natural products synthesis, see: (d) Chakraborty, T. K.; Pulukuri, K. K.; Sreekanth, M. Tetrahedron Lett. 2010, 51, 6444-6446; (e) Eto, K.; Yoshino, M.; Takahashi, K.; Ishihara, J.; Hatakeyama, S. Org. Lett. 2011, 13, 5398-5401; (f) Ishibashi, Y.; Ohba, S.; Nishiyama, S.; Yamamura, S. Tetrahedron Lett. 1996, 37, 2997-3000; (g) Larivée, A.; Unger, J. B.; Thomas, M.; Wirtz, C.; Dubost, C.; Handa, S.; Fürstner, A. Angew. Chem., Int. Ed. 2011, 50, 304-309.

3. (a) Revsez, L.; Blum, E.; Padova, F. E.; Buhl, T.; Feifel, R.; Gram, H.; Hiestand, P.; Manning, U.; Rucklin, G. Bioorg. Med. Chem. Lett. 2004, 14, 3595-3599; (b) Iwanowicz, E. J.; Watterson, S. H.; Guo, J.; Pitts, W. J.; Murali Dhar, T. G.; Shen, Z.; Chen, P.; Gu, H. H.; Fleener, C. A.; Rouleau, K. A.; Cheney, D. L.; Townsend, R. M.; Hollenbaugh, D. L. Bioorg. Med. Chem. Lett. 2003, 13, 2059-2063; (c) Dover,
L. G.; Coxon, G. D. J. Med. Chem. 2011, 54, 6157-6165; (d) Jean, D. J. S.; Fotsch, C. J. Med. Chem. 2012, 55, 6002-6020; (e) Meanwell, N. A. J. Med. Chem. 2011, 54 2529-2591.

4. Barbier, J.; Jansen, R.; Irschik, H.; Benson, S.; Gerth, K.; Böhlendorf, B.; Höfle, G.; Reichenbach, H.; Wegner, J.; Zeilinger, C.; Kirschning, A.; Müller, R. Angew. Chem., Int. Ed. 2012, 51, 1256-1260.

5. (a) Williams, D. R.; Brooks, D. A.; Berliner, M. A. J. Am. Chem. Soc. 1999, 121, 4924-4925; (b) Yokokawa, F.; Asano, T.; Shioiri, T. Org. Lett. 2000, 2, 41694172; (c) Yokokawa, F.; Asano, T.; Shioiri, T. Tetrahedron 2001, 57, 6311-6327.

6. Araki, H.; Katoh, T.; Inoue, M. Tetrahedron Lett. 2007, 48, 3713-3717; For recent examples of C-2 arylation on oxazole, see: (a) Flegeau, E. F.; Popkin, M. E.; Greaney, M. F. Org. Lett. 2008, 10, 2717-2720; (b) Flegeau, E. F.; Popkin, M. E.; Greaney, M. F. J. Org. Chem. 2008, 73, 3303-3306; (c) Verrier, C.; Hoarau, C. Marsais, F. Org. Biomol. Chem. 2009, 7, 647-650; (d) Verrier, C.; Martin, T.; Hoarau, C.; Marsais, F. J. Org. Chem. 2008, 73, 7383-7386; For synthesis of 2alkyloxazoles by cross-coupling reactions, see: (e) Pridgen, L. N. Synthesis 1984 1047-1048; (f) Counceller, C. M.; Eichman, C. C.; Proust, N.; Stambuli, J. P. Adv. Synth. Catal. 2011, 353, 79-83; (g) Lee, K.; Counceller, C. M.; Stambuli, J. P. Org. Lett. 2009, 11, 1457-1459; (h) Williams, D. R.; Fu, L. Org. Lett. 2010, 12, 808811.

7. Zhang, X.; Liu, J.; Sun, X.; Du, Y. Tetrahedron 2013, 69, 1553-1558.

8. Skepper, C. K.; Quach, T.; Molinski, T. F. J. Am. Chem. Soc. 2010, 132, $10286-$ 10292.

9. (a) Schröder, R.; Schöllkopf, U.; Blume, E.; Hoppe, I. Liebigs Ann. 1975, 533-546; (b) Miller, R. A.; Smith, R. M.; Karady, S.; Reamer, R. A. Tetrahedron Lett. 2002 43, 935-938; (c) Vedejs, E.; Luchetta, L. M. J. Org. Chem. 1999, 64, 1011-1014.

10. (a) Miyaura, N.; Suzuki, A. Chem. Rev. 1995, 95, 2457-2483; (b) Heravi, M. M.; Hashemi, E. Tetrahedron 2012, 68, 9145-9178; (c) Jana, R.; Pathak, T. P.; Sigman, M. S. Chem. Rev. 2011, 111, 1417-1492; (d) Magano, J.; Dunetz, J. R. Chem. Rev. 2011, 111, 2177-2250; (e) Fürstner, A.; Seidel, G. Tetrahedron 1995 51, 11165-11176.

11. Basar, N. B.; Liu, H.; Negi, D.; Sirat, H. M.; Morris, G. A.; Thomas, E. J. Org. Biomol Chem. 2012, 10, 1743-1745.

12. The alkyl bromides are less reactive than the corresponding iodides in lithiumhalogen exchange which provided the desired products in lower yields in the following Suzuki coupling.

13. Strotman, N. A.; Chobanian, H. R.; He, J.; Guo, Y.; Dormer, P. G.; Jones, C. M.; Steves, J. E. J. Org. Chem. 2010, 75, 1733-1739.

14. Eissenstat, M. A.; Weaver, J. D., III J. Org. Chem. 1993, 58, 3387-3390. 